University of Nebraska - Lincoln

DigitalCommons@University of Nebraska - Lincoln

3-1964

\title{
Comparative Behavior and Relationships of the Eiders
}

\author{
Paul A. Johnsgard \\ University of Nebraska-Lincoln, pajohnsgard@gmail.com
}

Follow this and additional works at: https://digitalcommons.unl.edu/biosciornithology

Part of the Ornithology Commons

Johnsgard, Paul A., "Comparative Behavior and Relationships of the Eiders" (1964). Papers in Ornithology. 63.

https://digitalcommons.unl.edu/biosciornithology/63

This Article is brought to you for free and open access by the Papers in the Biological Sciences at DigitalCommons@University of Nebraska - Lincoln. It has been accepted for inclusion in Papers in Ornithology by an authorized administrator of DigitalCommons@University of Nebraska - Lincoln. 


\title{
COMPARATIVE BEHAVIOR AND RELATIONSHIPS OF THE EIDERS
}

\author{
By Paul A. Johnsgard
}

One of the more controversial systematic problems existing in the family Anatidae concerns the taxonomic rank and evolutionary relationships of the four species of eiders, which are currently considered by the American Ornithologists' Union (1957) to comprise three genera (Somateria, Lampronetta, and Polysticta) in the diving duck subfamily Aythyinae. In 1945, however, Delacour and Mayr included the eiders in a single genus (Somateria) within the sea duck tribe Mergini. At present, Delacour (1959) considers the eiders a separate tribe, Somateriini, distinct from the other sea ducks, and placed near the dabbling duck tribe Anatini. The erection of this new tribe, and his recognition of Polysticta as a monotypic genus for the Steller Eider, was apparently the result of Humphrey's (MS, Univ. Mich.; 1958) anatomical studies. On the basis of both behavior and anatomy, I concluded (1960) that the most satisfactory taxonomic relegation of the eiders is to consider them part of the tribe Mergini, as originally proposed by Delacour and Mayr, but to accept two genera, Somateria and Polysticta. Woolfenden (1961), after examining the postcranial osteology of all four species of eiders, came to identical conclusions.

In my earlier paper several behavior patterns of the eiders were either unknown to me or were uncertain, and only general behavioral features of the sea ducks were discussed. Since that time I have obtained behavioral observations on all of the species of eiders. I have been able to make extended observations on captive specimens of the European race of the Common Eider (Somateria mollissima mollissima), the King Eider (S. spectabilis), and the Steller Eider (Polysticta stelleri) at the Wildfowl Trust, and recently I observed the sexual behavior patterns of wild Spectacled Eiders (Somateria fischeri) near Igiak Bay, Alaska. These latter observations have provided important additional evidence relating to my earlier views on the relationships of the eiders and make it possible to conclude with greater certainty behavioral homologies and probable isolating mechanisms in the eiders and their nearest relatives. The nomenclature used in this paper follows that of Delacour (1959).

Previous behavioral studies on the eiders have been relatively few. Hoogerheide (1950) described the behavior of the European race of the Common Eider in detail, and his terminology has been largely adopted by McKinney (In Delacour, 1959:26-29). McKinney has also (1961) provided a most important contribution to behavior studies of anatids by his detailed comparison of the displays of the European race of the Common Eider with those of the race of the Pacific coast of North America (Somateria mollissima v. nigra). The other races of the Common Eider have not as yet been studied behaviorally. The King Eider was first studied by Myres (MS, thesis Univ. British Columbia), and his terminology for that species has been used in the present paper. Myres' observations on the King Eider have not yet been published, but a few descriptive remarks on this species have been published by Höhn (1957) and Drury (1961). The Steller Eider has been studied in the region of Cold Bay, Alaska, by McKinney, but his observations are also as yet unpublished. Practically nothing has been reported on the behavior of the Spectacled Eider; Myres (MS) summarized the relatively little information he was able to collect on this species.

The purpose of the present paper is to inventory the sexual displays of all the species of eiders, to indicate homologous patterns wherever possible, and to examine the significance of these patterns as probable isolating mechanisms and indicators of evolutionary relationships. In accordance with current practice, behavior patterns believed 
to be ritualized (that is, those that have display function) are capitalized. Clearly homologous patterns in different species are normally given the same name, but where homology is uncertain or where it seems desirable to retain previous terminology differences, this has been done at my discretion.

\section{FEMALE CALLS AND DISPLAY MOVEMENTS}

Females of all species of eiders possess Inciting movements which vary somewhat in their degree of ritualization. In the three species of Somateria, they consist of only slightly ritualized alternating movements of threat (with the bill lowered and pointed toward an "intruder") and Chin-lifting toward the mate or potential mate (see fig. $2 a$, and McKinney, 1961:15). In these species the movements are often accompanied by wooden or throaty gog-gog-gog-gog calls. Such calling may also occur when the bird is not Inciting. Inciting in the Steller Eider takes a somewhat different and more highly ritualized form. In this species the female performs only a slight lateral threatening movement which is followed by a rapid and extreme Chin-lifting accompanied by a loud and raucous gua-haaa with each Inciting movement (fig. $2 f$ ). Typically, females of this species perform Inciting while swimming quite rapidly behind a male, whereas female Somateria incite in a variety of situations including periods when resting on land. Female Steller Eiders appear to lack the gog-gog-gog calls, but they do possess soft and guttural notes which they utter rapidly, possibly as a mild form of threat.

Females of all species of Somateria sometimes also exhibit displays which are normally part of the male display repertory and which are generally performed in an incomplete or aberrant fashion. These include several of the major male courtship postures (for example, Cooing-movements in the European race of the Common Eider, Pushing and Reaching in the King Eider) as well as Bathing, Upward-stretch, and Wing-flapping. These latter three movements do not appear to differ from normal bathing, shaking, and wing-flapping and thus may not actually represent displays.

Females of all species of eiders indicate their readiness to copulate by assuming a Prone posture on the water (fig. $2 b$ ) as do most or all of the other sea ducks. In the genus Somateria this posture is frequently assumed gradually, often being interspersed with slight Inciting movements toward potential intruders. In my observations of Steller Eiders it appeared that the Prone posture was assumed more directly and, once achieved, was held more rigidly than in the larger eiders. Such an immobile Prone posture is particularly typical of such sea ducks as the goldeneyes (Bucephala) and mergansers (Mergus). No obvious precopulatory female displays have been observed by me in any of the species of Somateria. However, I did once observe a female Steller Eider perform Bill-dipping and Preening-dorsally (in response to these same displays by the male) before assuming her Prone posture.

Females as well as males of all species of eiders indicate a disposition to take flight by facing into the wind, occasionally vigorously shaking the head laterally, with neck stretched vertically. The general body shake is sometimes also performed in this situation.

\section{MALE PAIR-FORMING DISPLAYS}

The eiders exhibit a wide variety of male courtship displays, many of which are very similar or seemingly identical to unritualized comfort movements. To economize on space, it would seem most practical to discuss postures common to most or all species first, indicating variations in performance by particular species, and then to take up displays unique to certain species.

Head-turning.-All species of eiders possess remarkable head and bill shapes and colorations, and it is not surprising that these morphological features, which are them- 

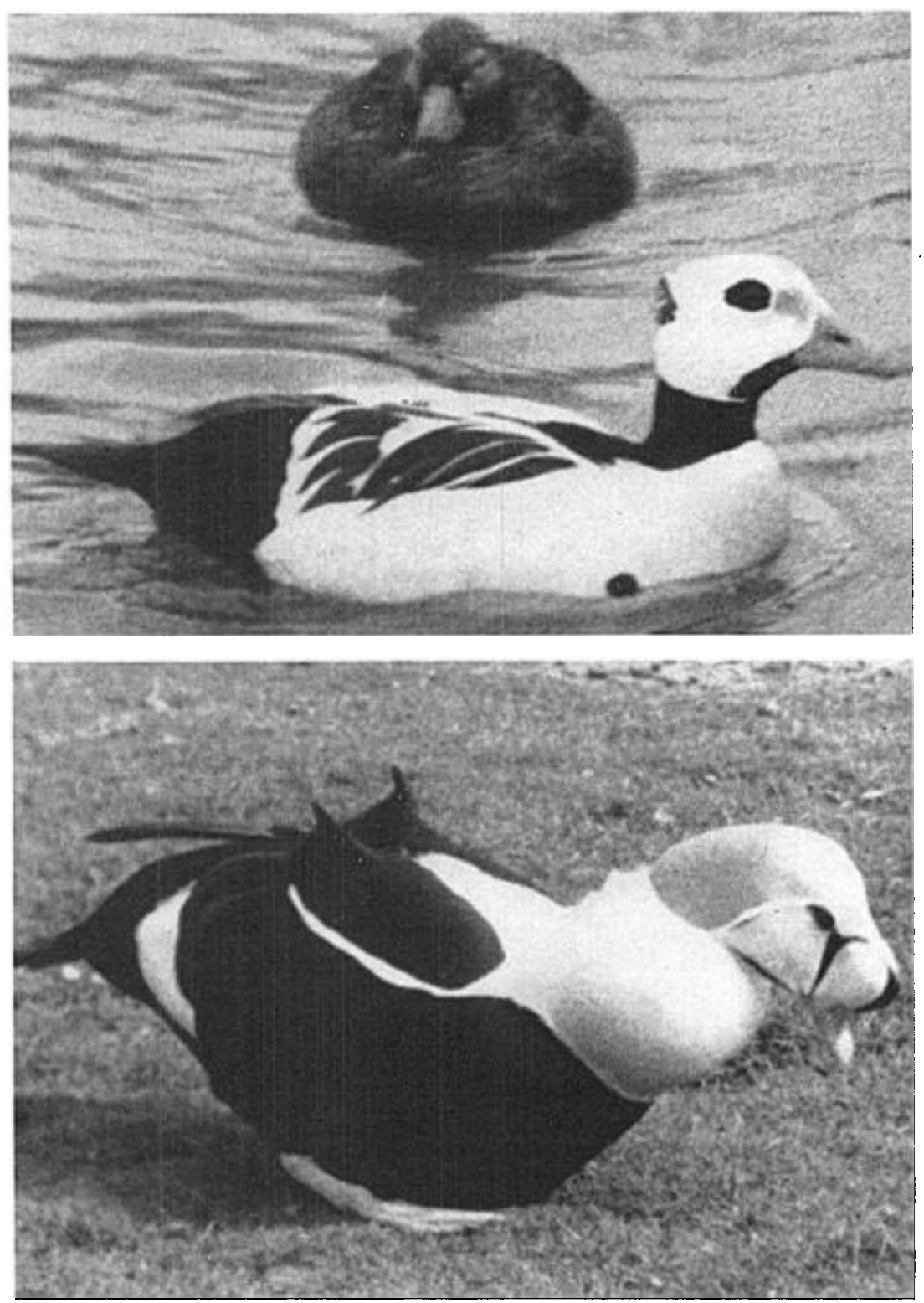

Fig. 1. Above: male Steller Eider Head-turning before female. Below: male King Eider Pushing on land.

selves species-specific, should be displayed in a common fashion. This is done by lateral Head-turning movements, with the bill held horizontal as the head is methodically swung back and forth (fig. 1). This swinging movement is shortest (producing an arc of about $45^{\circ}$ to $60^{\circ}$ ) and most rapid (approximately 2.8 arcs per second) in the Steller Eider and is most deliberate in the King Eider (approximately one arc per second), in which the head is swung through an arc of approximately $180^{\circ}$ (fig. $2 \mathrm{e}$ ). Head-turning is relatively infrequent in the Spectacled Eider, most often occurring after Rearing, 
when three or four fairly rapid turning movements are sometimes made. McKinney (1961) estimates that in the European race of the Common Eider the arc of head movement is approximately $90^{\circ}$; in this species Head-turning is usually a preliminary movement given before various other displays, whereas in the King Eider it is most frequently performed after such displays as Reaching and Pushing. In the Steller Eider, Headturning usually occurs both before and after the Rearing display, as the male approaches or rapidly swims ahead of an Inciting female (fig. $2 f$ ).

Upward-stretch.-This display, called the Shake by McKinney (1961), is obviously derived from the general swimming shake and differs little if at all from it. In the Common Eider and in the King Eider, where the movement appears to be of secondary importance as a display, it consists of pausing, rising in the water sufficiently far as to exhibit the black abdomen, rotating or shaking the head, then dropping back into the water again. In both these species the bill and head are held in a posture above the horizontal as they are shaken (illustrated in McKinney, 1961:13) in a manner similar to the Introductory Shake of dabbling ducks or pochards. The Upward-stretch of Spectacled and Steller eiders takes a markedly different form and represents a more conspicuous and important part of the total display activity. In both of these species the bird raises its breast rapidly out of the water, although not so far as in the preceding species, vigorously shakes its head with a distinctly downward tilt of the bill, then draws its head back and settles down into the water (fig. $2 g$ ). The only other species of duck in which I have observed a similar body shake is in the Black Scoter (Melanitta nigra).

Wing-flapping.-This display, which is called by Myres (MS) the Upward-stretch and Wing-flapping, is similar to the last in that it begins by the bird stopping in the water and raising the body almost vertically so as to exhibit most of the underparts. The bird pauses for a moment with opened wings, then flaps a few times and finally settles back down. In the Common Eider two rapid flaps are given, with the bill pointed about $45^{\circ}$ below the vertical plane; the male normally does not directly face a female during this display (fig. $2 b$ ). In the King Eider the display is even more highly ritualized. Besides limiting the flaps to two, the male usually faces the courted female and holds his head rigidly in line with the body in an almost vertical plane, clearly exposing the black " $V$ " on his throat to her vision (fig. $2 c$ ). Wing-flapping was rather infrequently observed in the Spectacled Eider and was more difficult to distinguish from normal wing-flapping, since there was no distinct pause before flapping and there appeared to be no orientation of the body toward the female (fig. $2 d$ ). I have not observed wing-flapping in the display of the Steller Eider and I do not believe it is ritualized in that species.

Chin-lifting.-The Chin-lifting performed by male eiders differs in no important respect from that performed by females. It appears to be an agonistic display, generally directed toward other males, and is silently performed (fig. $2 h$ ). In all species it is a rather rapid movement, and this is particularly the case in the Steller Eider, where the black throat of the male is momentarily exposed and hidden again.

Neck-stretching.-All of the species of Somateria have been observed Neck-stretching during courtship display. This posture is sometimes difficult to distinguish from the alert posture assumed when the birds are alarmed, and in addition, lateral Head-turning is often done while the neck is stretched vertically. However, McKinney (1961) recognizes this posture as a separate display in the Common Eider, and I believe it can be regarded as distinct in the King and the Spectacled eiders as well (see McKinney, 1961:9). Typically there is no call associated with the posture, but McKinney mentions hearing a soft woof at times in the European race of the Common Eider. I have 
not seen any posture which I would definitely call Neck-stretching in the Steller Eider, although an alert posture, with neck stretched and tail somewhat cocked, is usually assumed in advance of the Upward-stretch display.

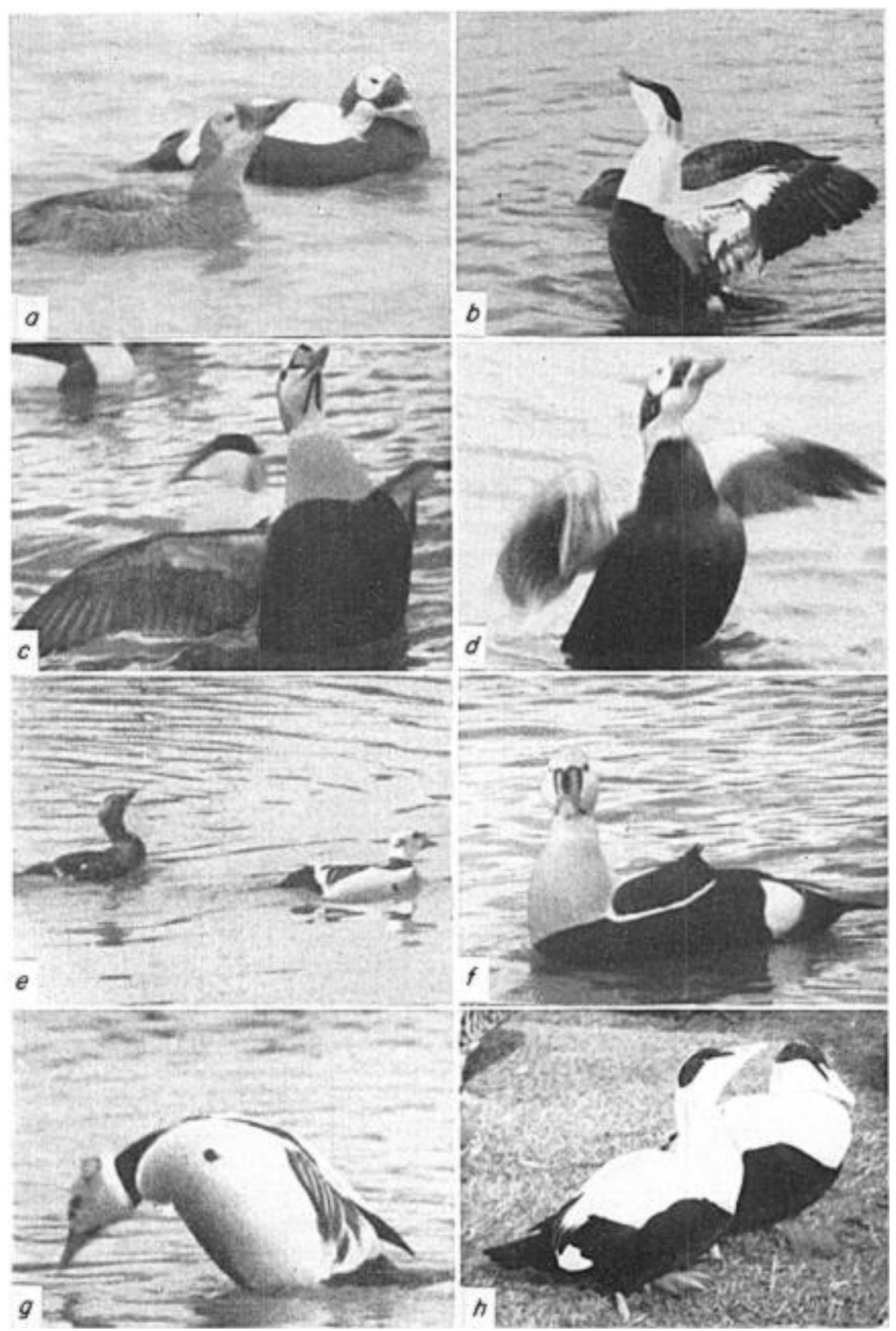

Fig. 2. $a$, female Spectacled Eider Chin-lifting during Inciting; $b$, European race of Common Eider, female Prone and male Wing-flapping; $c$, King Eider, male Wingflapping; $d$, Spectacled Eider, male Wing-flapping; $e$, Steller Eider, female Inciting and male Head-turning ; $f$, King Eider, male Head-turning ; $g$, Steller Eider, Upwardstretch; $h$, European race of Common Eider, Chin-lifting. 
Rearing, Head-forward-Rearing, Reaching, and Cooing-movement 3.-Although these four names are used for specific postures in each of the four species of eiders, there is good reason to believe that all of them are homologous. The strongest evidence supporting this view is the fact that in each species of eider the major male postcopulatory posture consists of one of these displays. Since postcopulatory displays are generally relatively conservative (Myres, MS; Johnsgard, 1961a), at least within genera, this lends support to the view that they are homologous displays. Each posture will be discussed in order:

Rearing.-This is the primary courtship and postcopulatory posture of the Steller Eider. It is normally performed as part of the following sequence: Alert posture-Upward-stretch-Steam toward female with Head-turning-Rearing-Steam away from female with Head-turning. The Rearing movement is an extremely rapid one, with the bird suddenly rising upward in the water without actually throwing his head back, momentarily exposing the dark chestnut undersides to the view of the female (fig. $3 a$ ), then instantly falling back on the water and veering away from her. Although $I$ have repeatedly seen this display performed from a distance of less than ten yards I have never heard any call accompanying it. Judging from Myres' (MS; 1959) descriptions of display in the Surf Scoter (Melanitta perspicillata), Rearing is very similar in form and is possibly even homologous to the Chest-lifting of that species, which display likewise serves both as a courtship and a postcopulatory posture. Independent Rearing sometimes also occurs in the Spectacled Eider (see Head-forward-Rearing beyond) and is performed in much the same way as in the Steller Eider, although in this species the chest is not lifted nearly so far out of the water (fig. $3 b$ ).

Head-forward-Rearing.- This is the name I gave to the primary courtship and postcopulatory display of the Spectacled Eider. This differs from ordinary Rearing in a few respects. Unlike the Rearing of the Steller Eider, it is not part of any rigid display sequence, although it most commonly occurs a few seconds after the Upward-stretch. Furthermore, there is a preliminary rapid movement of the head forward and slightly downward from a starting position with the neck stretched vertically. As the bill is about to touch the water (fig. $3 c$ ), the head is quickly jerked back onto the shoulders, producing a distinct lifting of the chest (fig. $3 d$ ). The degree of chest lifting is minor compared with that of the Steller Eider (and is even less than during independent Rearing as shown in fig. $3 b$ ), but it is sufficient to expose part of the blackish underparts. I have observed this display at distances as close as 30 yards but have been unable to hear any associated sounds. Furthermore, unlike the corresponding displays in the King and Common eiders, there is apparently no inflation of the neck during the display. Nonetheless, the basic head movements involved, namely, a thrust forward followed by an upward and backward retraction, are essentially identical to those in Reaching and Cooing-movement 3 . In my motion picture sequences I have found that Rearing is not always preceded by the Head-forward movement, and this independent Rearing more closely approaches the typical Rearing of the Steller Eider. In one such sequence, Rearing occurs in the absence of any immediately preceding or following displays, while in another it is both preceded and followed by Neck-jerking.

Reaching.--This is the name given by Myres (MS) to one of the primary pairforming displays of the King Eider. In fact, there is little reason for not calling it Cooing-movement 3 , for it corresponds in all important respects to that display of the Common Eider. Reaching begins with a marked vertical neck-stretching, followed by a deliberate swinging of the head and bill forward until the bill almost or actually touches the water (fig. $3 e$ ), and ends with a moderately fast retraction of the head back 
to a resting position (fig. $3 f$ ). While the head is swung down and forward the throat and chest appear to be inflated down to the limit of the white feathers, and as the head is drawn back a tremulous and owl-like hoo-oo-oo-oo call, gradually fading, is uttered.

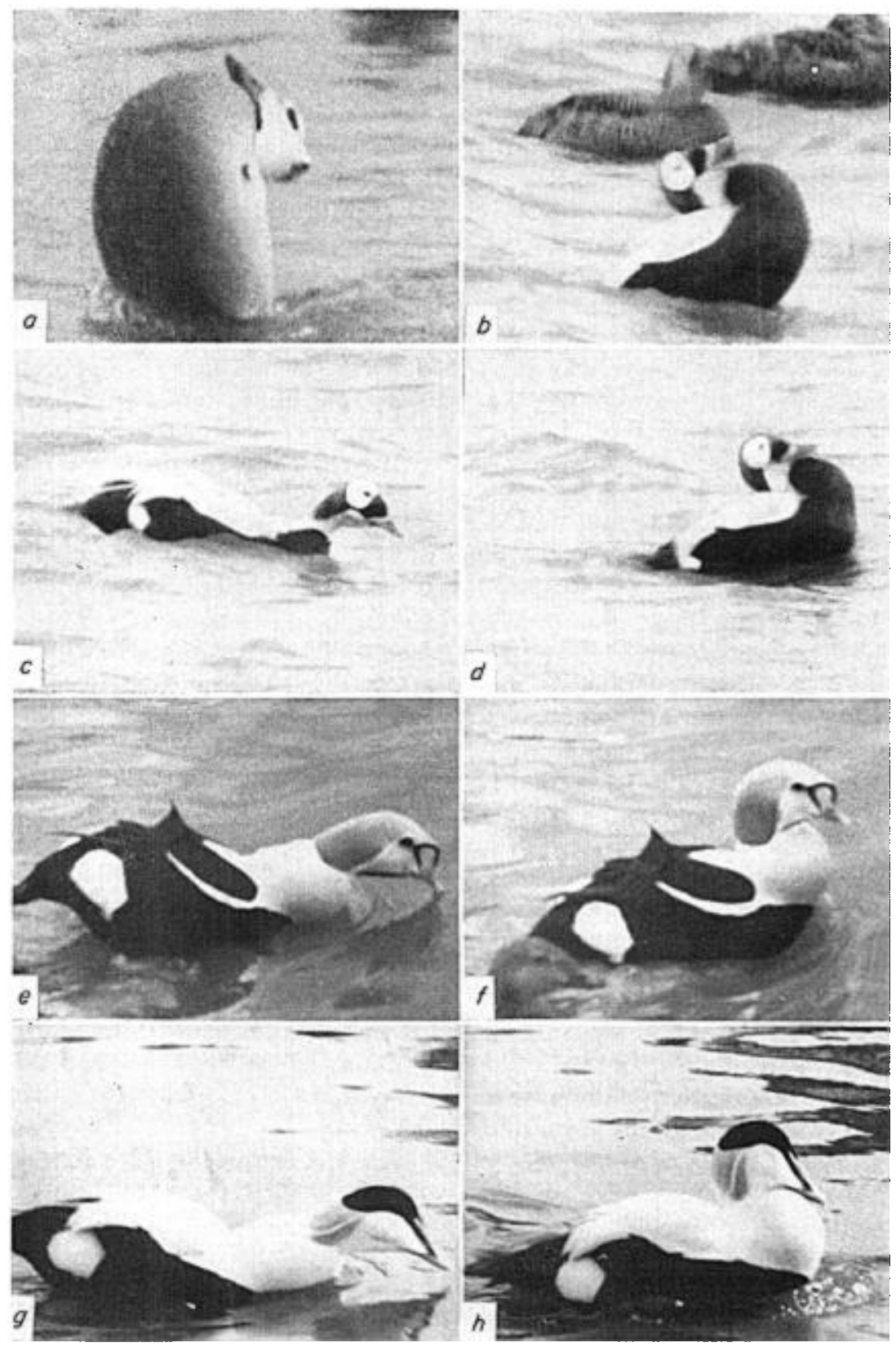

Fig. 3. $a$, Steller Eider, Rearing; $b$, Spectacled Eider, male Rearing; $c, d$, Spectacled Eider, Head-forward-Rearing; $e, f$, King Eider, two phases of Reaching; $g, h$, European race of Common Eider, two phases of Cooing-movement 3 . 
Although the chest is slightly raised as the display is terminated, this is not nearly so evident as in the preceding two species. Indeed, until I observed the distinctly intermediate display of the Spectacled Eider my only basis for believing that Rearing might be homologous to Reaching and Cooing-movement 3 was the fact that they all occurred in postcopulatory behavior. The Reaching display of King Eiders is generally followed by lateral Head-turning.

Cooing-movement 3-McKinney (1961) considers this display to be the least aggressive of the several cooing-movements performed by Common Eiders, and he observed it far more commonly in paired males than in aggressive males. It is performed in an identical manner to Reaching in the King Eider, the only important difference being in the call that is uttered (fig. $3 g, h$ ). In Common Eiders, including both the European and Pacific coast races, the call is a hoo-hooo of only two notes, the second being louder and quite prolonged. McKinney (1961) considers that the display has possibly evolved from a drinking movement, since the bill frequently touches the water during the middle phase of the display. However, the movements are quite different from those used during normal drinking and although I doubt such an origin I am unable to suggest an alternative one. In all four species, the display appears to be primarily one which emphasizes chest or underpart patterns; only in the King and Common eiders do vocalizations apparently play an important role. Considering the occurrence of the display in all four species of eiders in pair-forming as well as postcopulatory situations, I believe that this may well be considered the most fundamental single eider display, and it is the one which is most likely to have homologous equivalents in closely related genera.

Pushing.-Myres (MS) gave this name to a display which he first described in the King Eider, and which I have subsequently also recorded in the Spectacled Eider. Until recently $I$ believed that Pushing in the King Eider and Cooing-movement 2 of the Common Eider were probably homologous, but observations on the Spectacled Eider, which possesses both displays, forced abandonment of this idea. Pushing, as it occurs in the King Eider (fig. 1), is a fairly conspicuous and common display. From a resting position with the neck retracted, the head is rather deliberately pushed outward and upward, with the bill directed almost vertically downward, as if the bird were pushing with the crown of his head against some imaginary object (fig. $4 a$ ). At the same time the entire white area of the chest is greatly inflated, and a wavering hoooo accompanies each Pushing movement. The head is returned to a resting position between Pushing movements, which in this species usually number three or four, and occasionally more. The display is frequently followed by lateral Head-turning. Pushing in the Spectacled Eider is almost identical in form, the main differences being that it seems to be performed only a single time, and the chest is little if at all inflated (fig. $4 b$ ). Although some sound is doubtless uttered during this display in the Spectacled Eider, I have not been close enough to hear any vocalizations.

Cooing-movement 1 and Bill-toss.--This display was first described in the Common Eider as Cooing-movement 1 (Hoogerheide, 1950; McKinney, 1961), but it also occurs as the Bill-toss in Spectacled Eiders. In both species it consists of a rather rapid backward toss of the head and bill to approximately $45^{\circ}$ to $60^{\circ}$ above the horizontal, so that the head usually touches the back (fig. $4 c, e$ ). In the Common Eider it is accompanied by a cooing $a h$-hooo, but I have not been able to hear any calls in the Spectacled Eider. McKinney (1961) found that in the European race of the Common Eider the head is first raised upward and slightly outward with a down-tilted bill (as in Cooing-movement 2 beyond) before being tossed back, whereas in the race of the Common Eider 
on the Pacific coast ( $v$. nigra) the bill tends to remain horizontal or slightly uptilted. In the Spectacled Eider I have not definitely observed this display to occur independently (at any distance it is easily confused with Chin-lifting), but rather I have recorded

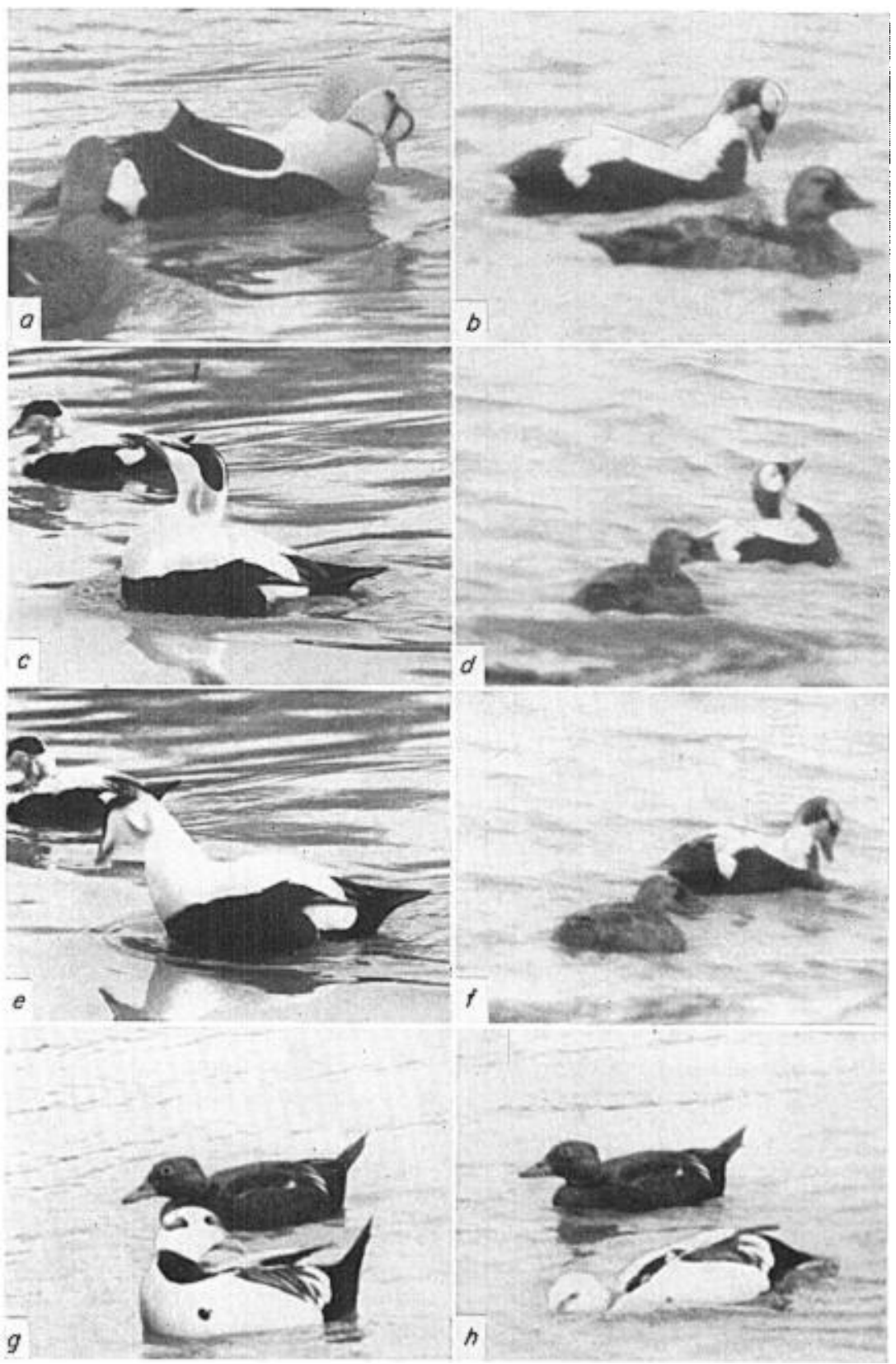

Fig. 4. $a$, King Eider, male Pushing; $b$, Spectacled Eider, male Pushing; $c$, European race of Common Eider, Cooing-movement $1 ; d$, Spectacled Eider, Bill-toss : $e$, European race of Common Eider, Cooing-movement 2 ; $f$, Spectacled Eider, Neck-jerking; $g$, Steller Eider, male Preening-dorsally; $h$, Stel'er Eider, male Bathing. 
it only as part of a linked display sequence involving Neck-jerking (see Bill-tossNeck-jerk beyond).

Cooing-movement 2 and Neck-jerking.-The display described as Cooing-movement 2 was first found in the Common Eider (Hoogerheide, 1950) and indeed has been recorded only in the European race of that species. McKinney (1961) failed to observe it in the course of intensive observations of $v$. nigra on the Pacific coast and believes it to be totally absent in that race. It consists of a rapid jerk upward and forward of the head and neck, similar to but much more rapid than the Pushing movement of King and Spectacled eiders (fig. $4 e$ ). It is always linked to Cooing-movement 1 , usually occurring after that display and forming a sequence called Cooing-movement $1+2$. The call associated with Cooing-movement 2 is much like that uttered during Cooing-movement 1 . Sometimes Cooing-movement 2 precedes rather than follows Cooing-movement 1 , and occasionally Cooing-movement 2 both precedes and follows Cooing-movement 1 , producing what are termed Double and Triple cooing-movements, respectively. Neck-jerking is the term I have given the corresponding display of the Spectacled Eider (fig. 4f), although it is seemingly identical to Cooing-movement 2 of the European race of the Common Eider. In fact, McKinney (1961) observed a "Neckjerk" in the European race which he found difficult to distinguish from Cooing-movement 2 or Neck-stretching, and I prefer the more descriptive term. In the Spectacled Eider I have not observed Neck-jerking to occur independently, but rather it appeared to be firmly linked to Bill-tossing or, less commonly, Rearing.

Bill-toss-Neck-jerk.-This display of the Spectacled Eider is simply a combination of Bill-tossing followed immediately by Neck-jerking and is exactly equivalent to Cooing-movement $1+2$ of the European race of the Common Eider (fig. $4 d, f$ ). In one of my film sequences there is a Bill-toss-Neck-jerk-Bill-toss series of linked displays, while another sequence shows a Bill-toss-Neck-jerk given twice in succession without interruption.

Preening.-Preening movements which do not outwardly differ from normal preening occur infrequently in the courting parties of the three species of Somateria. These include Preening-dorsally, Preening-behind-the-wing, and less frequent Preening in other areas. However, display Preening of any type is probably most properly regarded as a precopulatory display in eiders (fig. $4 g$ ).

Head-rolling.--Rubbing or rolling movements of the cheeks over the shoulders and back, often performed after Bathing, occur occasionally in the three species of Somateria, particularly in the Spectacled Eider. As McKinney (1961) noted, these movements are little modified from those involved in bathing and oiling. Head-rolling also commonly occurs during precopulatory display in these three species (illustrated by McKinney, 1961:13).

Bathing.-Vigorous bathing movements, with the head alternately dipped under water and quickly pulled back, splashing water over the body, have been observed during courtship in the larger eiders and during precopulatory display in the Steller Eider as well (fig. $4 h$ ). Like the two preceding displays, Bathing is practically identical to its corresponding comfort movement and occurs primarily in precopulatory situations. In Somateria it is usually followed by Wing-flapping, Head-rolling, or the Upward-stretch.

A summary of the distribution and probable homologies of these displays is presented in table 1. Presumably homologous postures are indicated in corresponding lines under each species, and those displays which are considered by me to be particularly well-developed and important in each species are printed in capital letters. 
TABLE 1

Comparison of Male Pair-Forming Displays in Polysticta and Somateria

\begin{tabular}{|c|c|c|c|}
\hline P. stelleri & S. fischeri & S. spectabilis & S. mollissima \\
\hline Head-turning & Head-turning & HEAD-TURNING & Head-turning \\
\hline UPWARD-STRETCH & UPWARD-STRETCH & Upward-stretch & Upward-stretch \\
\hline$\ldots$ & Wing-flapping & WING-FLAPPING & WING-FLAPPING \\
\hline Chin-lifting & Chin-lifting & Chin-lifting & Chin-lifting \\
\hline .............. & Neck-stretching & Neck-stretching & Neck-stretching \\
\hline REARING & $\begin{array}{l}\text { REARING ; HEAD- } \\
\text { FORWARD-REARING }\end{array}$ & REACHING & COOING-MOVEMENT 3 \\
\hline ........ & Pushing & PUSHING & ............. \\
\hline ................. & Bill-toss & ............. & COOING-MOVEMENT 1 \\
\hline ….... & Neck-jerk & (n.............. & Cooing-movement $2^{1}$ \\
\hline ......... & BILL-TOSS-NECK-JERK & .............. & $\begin{array}{l}\text { Compound cooing- } \\
\text { movements }\end{array}$ \\
\hline$\ldots . . .$. & Preening & Preening & Preening \\
\hline ............... & HEAD-ROLLING & Head-rolling & Head-rolling \\
\hline 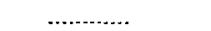 & Bathing & Bathing & Bathing \\
\hline
\end{tabular}

1 Absent from S. m. v. nigra.

Well-developed and important pair-forming displays are printed in capital letters.

\section{BEHAVIOR ASSOCIATED WITH COPULATION}

Copulation in all eiders is normally performed by mated pairs at a considerable distance from all unmated males, whose presence causes the female to resume Inciting, frequently even after she has assumed a Prone posture. It appeared to me that males of all species take the initiative in starting precopulatory sequences before the female begins to assume her Prone position. As the following accounts will indicate, copulatory behavior differs significantly in the four species.

Steller Eider.-Two complete and several additional incomplete copulations have been observed. In one instance both the male and female were observed to perform alternate Bill-dipping and Preening-dorsally before the female went into her Prone posture. Possibly similar mutual displays occurred before the other sequences too, but if so they were overlooked by me. In all cases the female, after assuming her flattened Prone posture, did not participate further in display. At about this point the male would immediately begin a series of vigorous Bathing movements, alternated every several seconds with Preening-dorsally in the region of the ornamental metallic-colored scapulars. Preening of the metallic wing speculum was not observed. This alternation of Bathing and Preening-dorsally continued in an uninterrupted fashion for possibly a minute or more, when it was suddenly terminated by a single Upward-stretch toward the female. Immediately after the Upward-stretch the male literally "surfboarded" across the water to the female and mounted immediately.

I have observed that the male Black Scoter also mounts the female immediately after performing a single Upward-stretch, and that Preening-dorsally and Preeningbehind-the-wing are important precopulatory displays in that species. Similarly, "Steaming" to the female occurs in both species of goldeneyes (Myres, 1959) and also in the Harlequin Duck, Histrionicus histrionicus (Neal G. Smith, pers. comm.). During treading, the male Steller Eider grasped the female's nape in the usual manner of anatids, but I have observed no Wing-flicks during copulation in this or any other species of eider. Wing-flicks during copulation do occur in some scoters, the goldeneyes, and some mergansers. In both observed instances, as copulation was terminated the male retained his grip on the female and the two birds Rotated slightly less than a 
complete revolution. He then released her, performed a single Rearing movement, and rapidly Steamed away while performing lateral Head-turning movements. The female then began to bathe.

Two aspects of the postcopulatory display are especially significant. These include the presence of Rotations, which are found most fully developed in the goldeneyes (Myres, 1959) but are absent or rudimentary in other sea ducks thus far studied. Secondly, the performance of Rearing as a postcopulatory display corresponds in form and context to the postcopulatory Chest-lifting of the Surf Scoter as described by Myres (1959). Thus, in the precopulatory Preening and Upward-stretch, and in the postcopulatory Rearing, the Steller Eider exhibits distinct similarities to scoters, while in a few other respects (Rotations, precopulatory and postcopulatory Steaming) it resembles such typical sea ducks as the goldeneyes. In no behavioral respect does the Steller Eider exhibit dabbling duck features, although Delacour (1959) believes that it is probably more closely related to members of the Anatini than is Somateria, or even the pochards (Aythyini).

Spectacled Eider.-Four copulations have been observed, three of them relatively completely, and the last was seen only from the time of mounting. In all cases the pair was separated by some distance from other drakes, and the precopulatory situation was recognized primarily by this fact. Like the other species of Somateria, the male performed an unpredictable and almost continuous series of displays. On the basis of limited counts these displays included the following, listed in order of decreasing observed frequency: Preening-behind-the-wing, Preening-dorsally, Pushing, Bathing, Headrolling, Bill-dipping and Wing-flapping. During this series of displays the female gradually assumed a Prone posture, and thereafter the male remained within six feet or less of her, displaying even more vigorously. In the three complete sequences seen, the male did not perform an Upward-stretch until just before mounting the female, just as in the Steller Eider. Unlike that species, however, there was no rapid Steaming to her after the Upward-stretch, but rather a fairly deliberate mounting. Treading lacked Wing-flicks, and as it terminated there was little if any indication of Rotations. The male then released the female, performed a single Head-forward-Rearing display, and then made about four lateral Head-turning movements without, however, swimming directly away from the female. The female usually bathed after copulation.

King Eider.-Four complete and several additional incomplete copulation attempts have been observed by me. Precopulatory behavior resembles in most respects that of both the Spectacled Eider and the Common Eider. The female gradually flattens out into a Prone posture as the male performs a continuous series of displays which include the two major courtship postures (Pushing and Reaching) but more typically include Bathing, Head-rolling, Wing-flapping, and the Upward-stretch. Unlike the two preceding species, the Upward-stretch may occur several times during the precopulatory sequence and does not appear to be a pre-mounting display. A common precopulatory sequence is Bathing followed by the Upward-stretch, Wing-flapping, or Head-rolling. On the basis of limited counts, the following precopulatory displays are listed in order of decreasing observed frequency: Bathing, Upward-stretch, Head-rolling, Wing-flapping, Reaching, Bill-dipping, multiple Pushing, and Preening-dorsally. In at least two of the four complete copulations seen, the display performed just prior to mounting was Wing-flapping, while in another it was the Upward-stretch. Copulation lacked Wing-flicks, and although the male retained his hold of the female's nape for a few seconds after copulation appeared to be terminated, it is probably not correct to describe this as a partial Rotation. After each of the four copulations the male performed 
a single Reaching display then swam away from the female fairly rapidly while performing lateral Head-turning movements. Although it may not be proper to consider this postcopulatory retreat from the female as Steaming, the relatively large size of the bird makes a very rapid Steaming improbable if not impossible.

Common Eider.-Although I have seen several complete copulations in the European race of the Common Eider, McKinney (1961) has provided extensive quantitative data on both the European and the North American Pacific coast races of this species. The general form of the precopulatory behavior appears to be the same in both races. McKinney believes that both sexes usually begin precopulatory behavior almost simultaneously; in my more limited observations on captive birds I felt that males normally initiated it well before the female became Prone. In normal precopulatory sequences, McKinney found that the most common male displays in the European race were, in approximate decreasing order, Bathing, Preening, Neck-stretch, Upward-stretch ("Shake"), Head-shake, Head-roll, Head-turning, Wing-flapping, and Cooing-movements. There were some differences between the two races in these frequencies. McKinney found that the final movement before mounting was quite variable but tended to be Head-turning or a Cooing-movement in the European race whereas Head-turning or the Upward-stretch was most typical of the Pacific coast race. However, both races were uniform in their postcopulatory behavior. After releasing the female, the male performs a single Cooing-movement 3, followed nearly always by lateral Head-turning. Females of both races normally bathe after copulation, but McKinney has also recorded various other postures or calls.

To summarize the more important aspects of these observations, the normal copuuatory behavior patterns of the four species of eiders are presented in table 2 . The most

TABLE 2

Comparison of Male Copulatory Displays in Polysticta and Somateria
$P$. stelleri
S. fischeri
S. spectabilis
S. mollissima

Precopulatory Displays

Bill-dipping

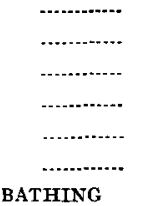

PREEN-DORSALLY

…….......

Pre-mounting Behavior

Upward-stretch

Steam to female

Postcopulatory Behavior

Incomplete Rotation

Rearing

Head-turning

Bill-dipping
Pushing
Head-rolling
Bathing.....
PREEN-BEHIND-WING
PREEN-DORSALIY
Wing-flapping

Upward-stretch

Head-forward-Rearing Head-turning

Bill-dipping
Pushing
HEAD-ROLLING
UPWARD-STRETCH
BATHING
Preen-behind-wing
Preen-dorsally
Wing-flapping
Reaching

Bill-dipping

Head-shaking NECK-STRETCHING

Head-turning Head-rolling UPWARD-STRETCH BATHING

Preen-behind-wing PREEN-DORSALLY Wing-flapping Cocing-movements

Wing-flapping? Variable

Reaching Head-turning
Cooing-movement 3 Head-turning

1 Based in part on McKinney (1961).

Most frequently observed displays are printed in capital letters. 
frequently observed displays are printed in capital letters, but the sequential arrangement is of no significance.

\section{DISCUSSION}

Conclusions of both taxonomic and evolutionary importance can be drawn from these observations. The sexual behavior patterns used during pair formation by all four species of eiders have a few elements in common, such as Upward-stretch, Headturning, Chin-lifting, which presumably are relatively conservative, or "primitive." Of these three, the Upward-stretch, or ritualized shake, is an important part of the courtship display repertory of the Black Scoter (Johnsgard, MS) and may also be a display in the White-winged Scoter, Melanitta deglandi (Myres, MS). In mergansers the Upward-stretch is both a pair-forming and precopulatory display (Johnsgard, $1961 b)$, and it is used during courtship in Bucephala. Lateral Head-turning is apparently a pair-forming display in the Surf Scoter (Myres, MS) and is an important display in goldeneyes (McKinney, 1961), where it has been called "Ticking" (Dane, Walcott, and Drury, 1959). Chin-lifting occurs in both sexes of eiders, but as a female display it is used during Inciting. Myres (MS) notes that Chin-lifting (apparently also used during Inciting) is the primary female display movement of all three species of scoters and also occurs occasionally in Oldsquaws (Clangula hyemalis).

In their copulatory behavior patterns, the eiders provide even stronger evidence indicating their affinities with the other sea ducks. Unlike the dabbling ducks, nearly all of which utilize mutual Head-pumping as a precopulatory display (Johnsgard, 1962), precopulatory behavior in eiders involves primarily male displays, while the female remains Prone. In all four species of eiders, Bathing and Preening form important components of precopulatory display. Myres (1959) has indicated the importance of precopulatory Preening in Bucephala and in the Surf and White-winged scoters, and I have observed precopulatory Preening in Black Scoters. Precopulatory Bathing is rather uncommon in the other sea ducks, but $I$ have observed it in both species of goldeneyes and believe that the precopulatory Water-twitch (Myres, 1959) of scoters and Buffleheads (Bucephala albeola) may represent low-intensity bathing movements. Furthermore, the occurrence of the Upward-stretch as a final pre-mounting display in the Steller and Spectacled eiders has its counterpart in the Black Scoter, and the precopulatory rush to the female in the Steller Eider is apparently also typical of the Harlequin. Finally, the postcopulatory Rearing display of the Steller Eider is strikingly similar to the postcopulatory Chest-lifting described by Myres (1959) for the Surf Scoter. Taken altogether, the weight of evidence that the closest relatives of the eiders are indeed the scoters and closely related genera (Histrionicus, Clangula, and probably Camptorhynchus) is considerably strengthened by behavioral findings.

The taxonomic problem of how many eider genera should be accepted is also somewhat easier to resolve now than previously. Besides the anatomical arguments for accepting Polysticta (Humphrey, 1958; Woolfenden, 1961), the behavior of the Steller Eider seems sufficiently distinct from the larger eiders to warrant generic separation. Significantly, however, the differences that Polysticta exhibits from the larger eiders are, by and large, actually convergences toward the scoter-like assemblage of species. Thus, in my opinion, the best reason for accepting Polysticta is to emphasize its status as a connecting form between the eiders and the rest of the sea ducks (Johnsgard, 1960). Parkes (1955) has reviewed the history of the name Lampronetta, which is currently accepted by the American Ornithologists' Union (1957). As he has pointed out, the validity of generically separating this species from the Common and King eiders 
on the morphological basis of feathering on the head and bill is extremely dubious. Behaviorally, the Spectacled Eider has a great deal in common with these two species, and I certainly agree that Lampronetta should be synonymized with Somateria. Yet, in sharing with the Steller Eider such displays as Rearing, a precopulatory Upwardstretch, and postcopulatory Rearing, the Spectacled Eider may be considered slightly less Somateria-like than the other two species. The diagram which I presented earlier (Johnsgard, 1961a) indicating probable relationships of the eiders has thus been more fully substantiated.

As a problem in evolution, the behavioral differences exhibited by the eiders are of particular interest. Behavioral inventories of all or nearly all of the living species of any waterfowl genus are extremely few; the studies of Lorenz (1951-1953) and myself (1961a, 1962) on the genus Anas, and of Myres (MS) on Bucephala and Melanitta might be mentioned as examples. While the present study is clearly not definitive and much remains to be learned about eider behavior, certain facts stand out clearly. One might cite first the tendency for shared homologous displays (for example, Headturning, Upward-stretch) to be performed at different speeds, intensities, or in different manners or contexts by the various species, so producing the necessary specificity. Likewise a linkage or repetition of shared display elements can be observed (for example, compound Cooing-movements of the European race of the Common Eider, multiple Pushing of King Eider) that results in unique sequences. Thus, display specificity utilizing a limited number of components can be achieved in several ways.

Second, the absence of certain displays from some of the species indicates either the ritualization of such displays after the initial splitting of ancestral gene pools or a secondary loss as a result of selective pressures for species-specificity. For example, the evolution of wing-flapping and neck-stretching into displays may have occurred after the separation of ancestral Polysticta stock, since these postures occur as displays in all three species of Somateria. The more intriguing possibility, that of a secondary loss of one or more display components, is strongly suggested in the eiders. McKinney (1961) found an apparently unaccountable difference in the behavior patterns of the European and Pacific coast races of Common Eider, in that the Pacific coast race of the Common Eider completely lacks Cooing-movement 2 together with the compound Cooing-movements of which this display is an integral part. At the time of McKinney's study, the displays of the King and Spectacled eider were practically unknown, and he was unable to account for this startling racial difference. Now, with the knowledge that the sympatric Spectacled Eider uses Neck-jerking (the homolog of Cooing-movement 2) as a major display, its absence from the Pacific coast race of the Common Eider is not only explainable but might almost have been predicted. In fact, the Billtoss-Neck-jerk of the Spectacled Eider is the exact corresponding pattern to Cooingmovement $1+2$ of the European race of the Common Eider. Throughout the range of the King Eider it is probably sympatric with either the Spectacled Eider, the Common Eider, or both, and wild hybrids have been recorded with the latter (Pettingill, 1959). Perhaps the King Eider's extreme elaboration of Head-turning and Wing-flapping (which are both of reduced importance in Spectacled Eiders) and its use of multiple Pushing (rather than the single Pushing movements of Spectacled Eiders) reflect this double problem of sympatric coexistence. On the other hand, it has apparently lost two major displays that are found in the other two species, the Bill-toss (or Cooingmovement 1) and the Neck-jerk (or Cooing-movement 2). Interestingly, all three species of Somateria have retained as an important pair-forming display the one homolooniss pattern that is used by all as a postcopulatory display (Head-forward-Rearing, 
Reaching, or Cooing-movement 3 ). This display is performed in much the same manner by all three species, but different calls and different degrees of chest inflation (? by interclavicular air sac) and final head retraction provide specificity. In the King and Common eider, which have a marked chest enlargement during this display, the anterior limits of the black underpart coloration and the posterior limits of chest inflation exactly coincide (see fig. 3). In the Spectacled Eider, which has little or no chest expansion, the black body coloration extends almost to the throat. In this species and in the Steller Eider the Rearing display clearly exhibits the black or chestnut underparts of these two respective species.

It may thus be seen that the behavior patterns of each of the eider species are apparently derived in a complex manner from inherited behavioral potentialities, which have been subjected to varying degrees of modification by the presence or absence of closely related species, and which have evolved in close harmony with plumage and soft part features. The correlations between the presence of lateral Head-turning and elaborate head and bill adornments, between extent of chest inflation and body plumage patterns, and between the precopulatory Preening of the Steller Eider and its ornamental scapulars are too obvious to be coincidental. In these species, as in many others which have been studied, the behavioral taxonomist using display characters must therefore constantly keep in mind the fact that he is dealing with features that function primarily as interspecific isolating mechanisms and which therefore must be expected to exhibit divergence through pressures of natural selection. Likewise the morphological taxonomist who contends, for example, that the genus Lampronetta should be recognized on the basis of head and bill feathering should realize that he too is using a character that is almost certainly a species-specific isolating mechanism and which is of little or no significance at the generic level.

\section{ACKNOWLEDGMENTS}

My observations on the Common, King, and Steller eiders were nearly all obtained at the Wildfowl Trust from 1959 to 1961 , while on postdoctoral fellowships from the National Science Foundation and the Public Health Service. I would like to express my appreciation to these agencies and to the staff of the Wildfowl Trust for making these studies possible. Observations on the Spectacled Eider were made during June of 1963 on a National Science Foundation research grant (GB 1030). During this time the kind assistance of Mr. James G. King, of Bethel, Alaska, did much to make the difference between success and failure.

\section{SUMMARY}

Pair-forming and copulatory displays of the four species of eiders are described and illustrated, based on observations of captive and wild specimens. Behavioral differences indicate that two genera (Polysticta and Somateria) of eiders should be recognized, and that Lampronetta should be considered a synonym of Somateria. Racial differences in the displays of Somateria mollissima mollissima and S. m.v.nigra are explained on the basis of sympatry between the latter and $S$. fischeri, producing selection for display divergence that has not affected $S . m$. mollissima. Similarities in the behavior patterns of the eiders and the scoters suggest that the eiders are directly related to the scoters and other sea ducks, probably through such intermediate forms as Camptorhynchus, Clangula, and Histrionicus, for which the behavior patterns are largely or entirely unknown. 


\section{LITERATURE CITED}

American Ornithologists' Union

1957. Check-list of North American birds. Fifth ed. (published by the Union, Baltimore, Md.).

Dane, B., Walcott, C., and Drury, W. H.

1959. The form and duration of the display actions of the goldeneye (Bucephala clangula). Behaviour, 14:265-281.

Delacour, J.

1959. The waterfowl of the world. Vol. 3 (Country Life Ltd., London).

Delacour, J., and Mayr, E.

1945. The family Anatidae. Wilson Bull., 57:3-55.

Drury, W. H., Jr.

1961. Observations on some breeding water birds on Bylot Island. Canadian Field-Nat., $75: 84-101$.

Höhn, E. O.

1957. Observations on display and other forms of behavior of certain Arctic birds. Auk, $74: 203-214$.

Hoogerheide, C.

1950. De Eidereenden, Somateria mollissima L., op Vlieland. Ardea, 37:139-161.

Humphrey, P. S.

1958. Classification and systematic position of the eiders. Condor, 60:129-135.

Johnsgard, P. A.

1960. Classification and evolutionary relationships of the sea ducks. Condor, 62:426-433.

1961a. The taxonomy of the Anatidae-A behavioural analysis. Ibis, 103a:71-85.

$1961 b$. The sexual behavior and systematic position of the hooded merganser. Wilson Bull., $73: 226-236$.

1962. Evolutionary trends in the behaviour and morphology of the Anatidae. Wildfowl Trust 13th Annual Report, pp. 130-148.

Lorenz, K. Z.

1951-1953. Comparative studies on the behaviour of the Anatinae. Avic. Mag., 57:157-182; $58: 8-17,61-72,86-94,172-184 ; 59: 24-34,80-91$.

- McKinney, F.

1961. An analysis of the displays of the European eider Somateria mollissima mollissima (Linnaeus) and the Pacific eider Somateria mollissima v. nigra Bonaparte. Behaviour, Suppl. 7:vii + 1-124.

Myres, M. T.

1959. Display behavior of bufflehead, scoters and goldeneyes at copulation. Wilson Bull., $71: 159-168$.

Parkes, K. C.

1955. The generic name of the spectacled eider. Auk, 72:85-86.

Pettingill, o. S., Jr.

1959. King eiders mated with common eiders in Iceland. Wilson Bull., 71:205-207.

Woolfenden, G. E.

1961. Postcranial osteology of the waterfowl. Bull. Florida State Mus., 6, No. 1:1-129.

Department of Zoology and Physiology, University of Nebraska, Lincoln, Nebras$k a$, June 28, 1963. (This is paper No. 358 of Studies from the Department of Zoology and Physiology of the University of Nebraska.) 